\title{
Eviction, Health Inequity, and the Spread of COVID-19: Housing Policy as a Primary Pandemic Mitigation Strategy
}

\author{
Emily A. Benfer (1) - David Vlahov • Marissa Y. Long • \\ Evan Walker-Wells • J. L. Pottenger Jr.・ Gregg \\ Gonsalves • Danya E. Keene
}

Accepted: 25 November 2020 / Published online: 7 January 2021

(C) The New York Academy of Medicine 2021, corrected publication 2021

\begin{abstract}
The COVID-19 pandemic precipitated catastrophic job loss, unprecedented unemployment rates, and severe economic hardship in renter households. As a result, housing precarity and the risk of eviction increased and worsened during the pandemic, especially among people of color and low-income populations. This paper considers the implications of this eviction crisis for health and health inequity, and the need for eviction prevention policies during the pandemic. Eviction and housing
\end{abstract}

The original version of this article was revised: As a result of an error during the publication process, the middle initial of coauthor Danya E. Keene was incorrectly presented in this article as originally published as "A.".

E. A. Benfer $(\bowtie)$

Wake Forest University School of Law, 1834 Wake Forest Road, Winston Salem, NC 27109, USA

e-mail: benfere@wfu.edu

D. Vlahov

Yale School of Nursing, New Haven, CT, USA

M. Y. Long

Columbia University Mailman School of Public Health, New

York, NY, USA

E. Walker-Wells · J. L. Pottenger Jr.,

Yale Law School, New Haven, CT, USA

G. Gonsalves

Yale School of Public Health, Yale Law School, New Haven, CT, USA

D. E. Keene

Yale School of Medicine, Yale School of Public Health, New Haven, CT, USA displacement are particularly threatening to individual and public health during a pandemic. Eviction is likely to increase COVID-19 infection rates because it results in overcrowded living environments, doubling up, transiency, limited access to healthcare, and a decreased ability to comply with pandemic mitigation strategies (e.g., social distancing, self-quarantine, and hygiene practices). Indeed, recent studies suggest that eviction may increase the spread of COVID-19 and that the absence or lifting of eviction moratoria may be associated with an increased rate of COVID-19 infection and death. Eviction is also a driver of health inequity as historic trends, and recent data demonstrate that people of color are more likely to face eviction and associated comorbidities. Black people have had less confidence in their ability to pay rent and are dying at 2.1 times the rate of non-Hispanic Whites. Indigenous Americans and Hispanic/Latinx people face an infection rate almost 3 times the rate of non-Hispanic whites. Disproportionate rates of both COVID-19 and eviction in communities of color compound negative health effects make eviction prevention a critical intervention to address racial health inequity. In light of the undisputed connection between eviction and health outcomes, eviction prevention, through moratoria and other supportive measures, is a key component of pandemic control strategies to mitigate COVID-19 spread and death.

Keywords COVID-19 · Pandemic · SARS-CoV-2 . housing $\cdot$ health $\cdot$ eviction $\cdot$ homelessness $\cdot$ health equity health justice $\cdot$ health inequity $\cdot$ policy $\cdot$ housing instability $\cdot$ moratoria $\cdot$ moratoriums $\cdot$ public health . primary prevention $\cdot$ pandemic mitigation 


\section{Introduction}

The COVID-19 pandemic precipitated catastrophic job loss and economic hardship, especially among people of color and low-income populations who were already economically marginalized and experiencing severe housing precarity. In 2016, the last available year of nationwide eviction data, 3.7 million evictions were filed nationally [1], disproportionately affecting Black and Hispanic renters [2]. Due to stagnant wages, rising rents, and lack of federal financial support, one out of four (10.9 million) renters nationally spent over half of their income on housing before the pandemic [3]. The cost burden is even greater among households in poverty: one out of four spent over $70 \%$ of their income on rent in 2018 [4]. With the loss of 4 million affordable housing units from 2011 to 2017 [5] and a shortage of 7 million affordable units available to the lowest-income renters [6], many renters entered the pandemic vulnerable to eviction.

The pandemic-driven economic recession hits in the midst of this pre-existing affordable housing crisis to create a threat of mass evictions and increased housing displacement. In the absence of legal, economic, and social support to low- and middle-income people in the USA - a feature of the response in many other countries [7], strategies to control the pandemic, such as social distancing and business closures, led to unprecedented unemployment and wage loss among renter households [8]. Furthermore, low-income and predominantly minority communities, who were already economically marginalized, experienced disproportionate economic hardship and impacts of the virus itself [9]. COVID-19 morbidity and mortality in these populations and communities likely further exacerbated economic hardships. Together, these factors have created an unprecedented eviction and housing crisis that disproportionately affected low-income populations and communities of color.

Eviction and housing displacement are associated with increased COVID-19 infection and mortality rates. $[10,11]$ Eviction and housing instability provide a wide array of COVID-19 transmission opportunities that have had the effect of undermining mitigation strategies and stifling pandemic control efforts. Eviction immediately leads to overcrowding, doubling up, homelessness, and housing instability. These increase contact with others and hinder compliance with the strategies necessary to contain COVID-19, including social distancing, self- quarantining, and hand hygiene (see Fig. 1.) In the long-term, eviction results in severe and lasting poor health outcomes and economic costs that further threaten individual health and well-being and hampers pandemic control and recovery. This article presents the circumstances and mechanisms to suggest how eviction and housing displacement can further COVID-19 infection and death. We marshal evidence to suggest that eviction moratoria and other housing stabilization measures are a critical component of any comprehensive strategy to control the COVID-19 pandemic.

\section{Eviction Increases the Risk of COVID-19 Acquisition and Transmission}

\section{Transiency and Overcrowding Spread COVID-19}

COVID-19 spreads through direct person-to-person contact, indirect surface contact, and the exposure to and/or inhalation of infectious droplets (particles $>$ $5 \mu \mathrm{m}$ ) and aerosols (particles $<5 \mu \mathrm{m}$ ) [12]. Respiratory plumes which typically extend $1.5 \mathrm{~m}$ or $\sim 5 \mathrm{ft}$. from an infected person are the most common pathway for viral transmission [13]. Indoor environments without sufficient ventilation can contribute to an accumulation of airborne aerosols resulting in transmission between individuals farther apart than $1.5 \mathrm{~m}$ [14]. For these reasons, the Centers for Disease Control and Prevention's (CDC) primary pandemic interventions, including social distancing, maintaining good hygiene practices, self-quarantining, cleaning masks and other personal protective equipment, and limiting or restricting indoor gatherings, have been effective in reducing the spread of COVID-19 [15, 16]. However, eviction and housing displacement force families into transiency, homelessness, and crowded residential environments [17-20] that increase new contact with others and make compliance with pandemic health guidelines difficult or impossible. Eviction increases the likelihood of "couch surfing," residing in shelters, sleeping in cars or outdoors, and doubling up with friends and family who may themselves be at risk for COVID-19 [17, 18, 20, 29].

Using an analogy of other infectious diseases such as tuberculosis, influenza, and meningococcal disease, even seemingly small differences in housing have been linked to substantial increases in transmission rates [21, 22]. Residential crowding and increased contact with 


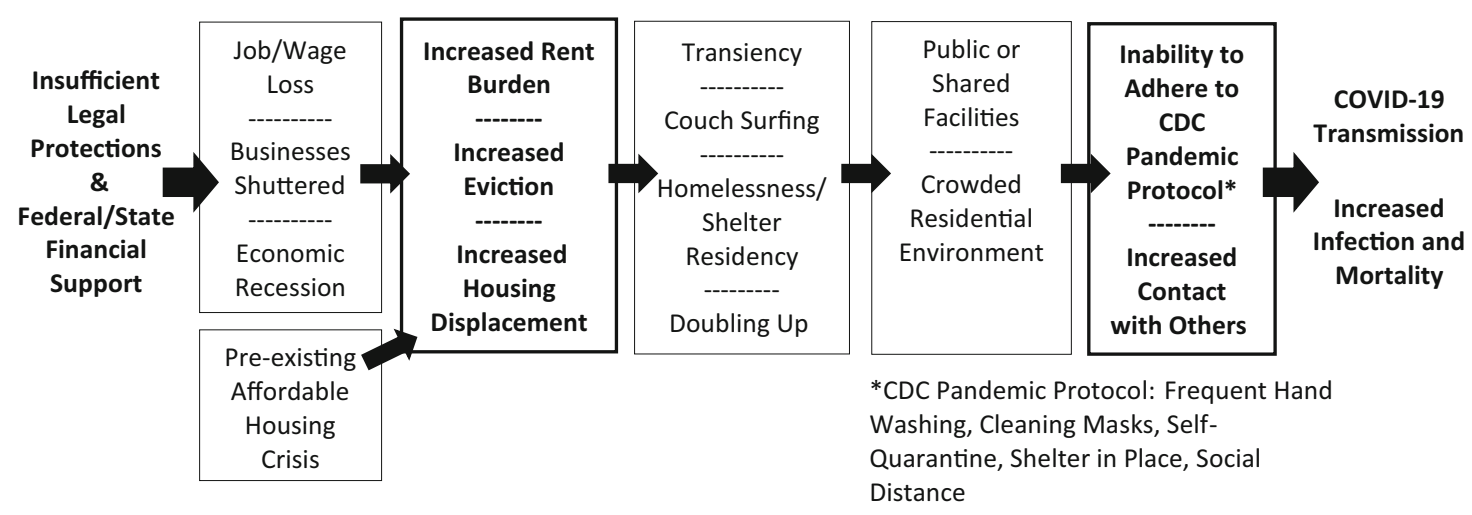

Fig. 1 Eviction increases the risk of COVID-19 acquisition and transmission

others drive the spread of infectious respiratory illnesses, such as COVID-19 [23-26]. Adding as few as two new members to a household can as much as double the risk of illness [27]. This increased likelihood of transmission for infectious disease generally comports with research on COVID-19, which recognizes that individuals are at particularly high risk of contracting COVID-19 from others in their household [28].

Studies suggest that overcrowding increases the spread of respiratory infectious diseases, such as tuberculosis [29] and severe cases of influenza among children [30], which are transmitted similarly to COVID-19. During the 1918 influenza epidemic, the difference between having 45 square feet and 78 square feet of living space per person was associated with a tenfold increase in the rate of illness [31]. Smaller, crowded spaces and shared facilities are commonplace in homeless shelters. In some U.S. cities, homeless shelters are required to provide as little as 25 square feet of space per person [32]. In many cases, people facing homelessness will sleep in cars or outdoors and be forced to use public facilities [33].

These environments prevent individuals and families from adhering to the CDC's primary pandemic interventions and increase the likelihood that evicted and displaced households are likely to contract-and spread-COVID-19 while moving from shelter to shelter or couch to couch [34]. Eviction leads to a reliance on informal housing safety nets that are common in lowincome communities. Most individuals who are unable to afford housing do not live in shelters or on the street but rather with friends and family members $[35,36]$. These often-transient shared housing arrangements increase the likelihood of exposure to the virus, compounded by the fact that members of these vulnerable households often work in occupations with a higher risk of exposure.

The risk of transmission is especially high among transient populations because infected persons can spread COVID-19 before they start to show symptoms and possibly for weeks after symptoms appear [37]. According to the CDC, approximately $40 \%$ of infected individuals may never show symptoms - but nonetheless may transmit the virus to others [25]. Due to the high rate of transiency among people who face eviction, eviction is likely to spread COVID-19 by exposing healthy individuals to those who are unaware they are carrying the virus or those who know they have COVID-19 but are unable to self-isolate [10].

The behavioral and physiological responses to eviction likely heighten the spread of infectious diseases, including respiratory illness and the flu. The mere threat of eviction can increase stress levels, anxiety, and depression - all of which can weaken the immune system $[38,39]$. Because of the highly contagious nature of COVID-19, increased acquisition of infection among individuals facing eviction can quickly boost transmission across a large segment of the community.

Eviction may also lead to lower access to COVID-19 testing [40] and medical attention by driving families to poorer, underresourced neighborhoods, and medically underserved geographic areas with fewer medical facilities and providers, in addition to decreased care affordability [41]. Even when infected individuals present with COVID-19 symptoms, eviction decreases the likelihood that they will seek timely medical attention that could stem community transmission [20]. Eviction is associated with decreased access to primary and specialty medical care, regardless of an individual's housing status post-eviction $[42,43]$ (p66). In addition, those 
facing evictions have difficulty responding to their health needs while struggling to maintain housing [44]. From this baseline, eviction itself amplifies the individual risk of COVID-19 complications and mortality. This can be particularly harmful to people who are already at risk, such as people immunocompromised due to cancer care, HIV/AIDS, or other conditions [45-48]. Evicted individuals are also more likely to use emergency departments, which cater to disproportionately vulnerable patients $[49,50]$, for their healthcare needs when they do seek care [20](p3), increasing their exposure to a sicker patient population.

Eviction Results in Comorbidities and Affects People with Chronic Conditions That Increase Vulnerability to COVID-19

People most vulnerable to eviction are also more likely to suffer from poor health conditions that place them at high risk of severe or fatal cases of COVID-19 [20]. The $\mathrm{CDC}$ has identified several comorbidities that increase the risk of severe illness with COVID-19, including pulmonary disease, high blood pressure, diabetes, obesity, chronic liver or kidney disease, and respiratory disease $[51,52]$. People at the highest risk of eviction are also more likely to live in substandard housing conditions that threaten their health [53], such as poor ventilation, pest infestations, and mold - all closely associated with the development of respiratory conditions and general poor health [54]. All of these conditions are more prevalent among low-income populations and people of color, the populations most at risk of eviction prior to and during the pandemic. [20, 55, 56]

Eviction and housing instability are associated with numerous comorbidities, including increased incidence of high blood pressure, higher mortality regardless of cause [57], increased risk of coronary heart disease independent of other underlying risk factors [38, 39](p205), poor self-reported general health [39](p202,204), and an increased propensity to smoke [58]. Evictions are associated with several interrelated conditions including sexually transmitted infections [43](p65), HIV-related treatment outcomes [42](p7-8), and drug use [59]. Eviction, and the mere threat of eviction, is also associated with numerous mental health conditions including anxiety, depression [39], exposure to violence [60], mental health hospitalization [20](p3), and suicide [57](p412-13). For women, eviction is associated with physical and sexual assault [61], drug use and related harms [62], mental illness [63], and future housing precarity [64]. The health conditions and high health care costs associated with eviction make future evictions more likely [65-67]. In this way, eviction deepens long-standing patterns of economic and housing instability and poor health, making it a threat to public health independent of the COVID-19 pandemic $[64,67,68]$ (see Table 1).

Eviction is particularly traumatizing to children and affects emotional and physical well-being and development for years, if not for lifetimes [69]. Eviction increases the likelihood of emotional trauma, lead poisoning [66, 70], food insecurity [71], and academic decline for children [64, 66, 72, 73]. Eviction is also strongly associated with adverse childhood experiences, which have long-term negative health impacts, including increased risk of cardiovascular disease and pulmonary disease in adulthood and decreased life expectancy [74]. Children whose mothers are evicted during pregnancy are more likely to have adverse birth outcomes, such as low birthweight or pre-term pregnancies [75]. Families of children born with adverse birth outcomes are substantially more likely to be evicted in the first 5 years of their child's life [64, 65]. The evidence is clear: Child health and housing security are closely intertwined [76].

Eviction threatens individuals' health in other ways [17(p91),77, 78]. Evictions force renters to the outskirts of the rental market, into neighborhoods with higher crime, increased poverty, and substandard conditions [79]. Eviction creates a permanent legal record, no matter the outcome of the proceeding, that allow landlords to screen tenants with a history of eviction and ultimately preclude them from future renting opportunities [80].

Eviction during COVID-19 Perpetuated Health Inequity among Black and Latinx People and Women

People of color were already more likely to be at risk of housing loss, due, in part, to historic and ongoing racially discriminatory housing opportunities and constraints that are only exacerbated by the racially disproportionate effects of the pandemic. Historic trends and recent data demonstrate that people of color are more likely to face eviction during the pandemic. Racial disparity in an eviction is evident as numerous studies demonstrate that Black renters faced eviction at the highest rates before COVID-19 [2, 81]. One study determined that Black households were more than twice as likely as White households to be evicted [2](p117). A review of several 
Table 1 Eviction leads to negative health outcomes \& future hardship

\begin{tabular}{|c|c|c|c|c|c|}
\hline Physical Health & Mental Health & $\begin{array}{l}\text { Associated Conditions } \\
\text { Among Women }\end{array}$ & $\begin{array}{l}\text { Associated Conditions } \\
\text { Among Children }\end{array}$ & $\begin{array}{l}\text { Exposure to } \\
\text { Sub-Standard } \\
\text { Living } \\
\text { Conditions }\end{array}$ & $\begin{array}{l}\text { Barriers to } \\
\text { Livelihood }\end{array}$ \\
\hline $\begin{array}{l}\text { - Higher Mortality } \\
\text { Rate }\end{array}$ & - Depression & - Physical Assault & - Lead Poisoning & - Lead & - Failing credit scores \\
\hline $\begin{array}{c}\text { Respiratory } \\
\text { Conditions }\end{array}$ & - Anxiety & - Sexual Assault & - Academic Decline & - Mold & - Downward move \\
\hline $\begin{array}{l}\text { - High Blood } \\
\text { Pressure }\end{array}$ & $\begin{array}{l}\text { - Mental Health } \\
\text { Hospitalization }\end{array}$ & $\begin{array}{l}\text { - Drug Use and Related } \\
\text { Harms }\end{array}$ & - Food Insecurity & - Poor Ventilation & - Unemployment \\
\hline $\begin{array}{r}\text { - Poor Self-Rated } \\
\text { General Health }\end{array}$ & $\begin{array}{l}\text { - Exposure to } \\
\text { Violence }\end{array}$ & - Pre-term Pregnancies & - Emotional Trauma & - Pest & $\begin{array}{r}\text { - Residential } \\
\text { instability }\end{array}$ \\
\hline $\begin{array}{l}\text { - Coronary heart } \\
\text { Disease }\end{array}$ & - Suicide & $\begin{array}{l}\text { - Future Housing } \\
\text { Instability }\end{array}$ & $\begin{array}{l}\text { - Risk of Chronic } \\
\text { Disease in Adulthood }\end{array}$ & - Infestations & - Homelessness \\
\hline $\begin{array}{l}\text { - Sexually } \\
\text { Transmitted } \\
\text { Infections }\end{array}$ & & & - Low Birthweight & - Crowding & $\begin{array}{c}\text { - Inability to access } \\
\text { social services }\end{array}$ \\
\hline • Drug Use & & & $\begin{array}{l}\text { - Decreased Life } \\
\text { Expectancy }\end{array}$ & & \\
\hline
\end{tabular}

studies conducted in multiple cities between 1991 and 2002 found that approximately $80 \%$ of people facing eviction were from non-White households [82]. PreCOVID-19, Black women were evicted at higher rates than other groups [17](p21), with 1 in 5 Black female renters reporting that they have experienced eviction compared with 1 in 12 Hispanic/Latinx women and 1 in 15 White women [83]. Of all gender and race combinations, Black women renters are at the highest risk: In 17 out of 36 states studied, Black women faced eviction filings at double the rate of White renters [84].

For people of color, who have one-twelfth of the wealth accumulation of White people [85] due to decades of racially discriminatory U.S. housing policy [86], the loss of employment or an unexpected emergency can precipitate greater hardship and housing instability. Over $70 \%$ of Black and Latinx adults entered the pandemic lacking emergency funds to cover 3 months of expenses, while over half of White adults had such savings [87]. Without a safety net, the downward fall is likely to be immediate and precipitous, and recovery may be impossible.

Eviction prevention is critical to containing the COVID-19 pandemic and protecting all Americans regardless of race. But, for people of color, who were significantly more likely to have no confidence in their ability to pay rent throughout the pandemic [88] and experience complications and death from COVID-19, avoiding eviction can be lifesaving. The CDC reports
Black Americans are dying at 2.1 times the rate of nonHispanic Whites [89]. Indigenous Americans as well as Hispanic/Latinx persons face an infection rate almost 3 times the rate of non-Hispanic Whites [89]. Asian, Black, and Hispanic/Latinx persons are 1.3, 4.7, and 4.6 times more likely to be hospitalized with COVID19, respectively, than non-Hispanic Whites [90]. Others have found similarly stark disparities in COVID-19 death rates: 2.3 times higher for Black people, 1.5 for Hispanic and Latinx [90], and 1.75 for indigenous people [91]. Black and Hispanic/Latinx people are dying at the rate of White people a decade or older [92]. These data underscore the extreme health inequity occurring during the pandemic.

The deep underlying health disparity can be traced to the inability to social distance in many low-wage jobs, crowded living conditions due to poverty and eviction, bias among health care providers, and disparate access to health care [93]. Other social determinants of health, like poverty and access to clean air and water, have driven larger proportions of people of color to develop comorbidities with COVID-19, like asthma or hypertension, that contribute to higher mortality rates. Furthermore, repeated exposure to racism in its many forms acts as a form of toxic stress that chips away at the body. This process of "weathering" results in health deterioration, the onset of chronic conditions, and premature aging at the cellular level, all of which likely play a prominent role in COVID-19 disparities [94]. 
The disproportionate impact of the economic recession, risk of eviction and associated harms, and COVID19 infection and mortality affect people of color at disproportionate rates and make it clear that health equity and social justice are deeply intertwined, especially in the pandemic setting. Protecting public health during the pandemic requires protecting those most likely to contract, spread, and die from COVID-19, especially people in poverty and people of color, who are more likely to be evicted and more likely to suffer severe harm during the pandemic. Public health and health justice require that all people have equal opportunity to achieve good health and protect themselves from COVID-19 $[91,95]$. This requires providing supports and intervention to prevent eviction and its corollary harms, including the spread of COVID-19.

\section{Policy Interventions to Prevent Eviction Reduce the Spread of COVID-19}

\section{Moratoria Can Effectively Limit Eviction Filings}

During the pandemic, governors, courts, and legislative bodies in 43 states issued eviction moratoria that varied in duration, stage of eviction frozen, and the type of eviction forestalled [96, 97]. These moratoria had a chilling effect on eviction filings. The Eviction Lab's research on eviction filings in 25 cities [98] during the pandemic shows that (1) where state or local eviction moratoria were in place, the intervention effectively slowed eviction filings during the pandemic and (2) without moratoria in place, eviction filings quickly reached or exceeded historic filing rates [98]. Similar outcomes occurred with federal moratoria. Along with the stimulus and extended federal unemployment benefits, the CARES Act slowed evictions by effectively prohibiting eviction of tenants in buildings with federally backed mortgages or federal subsidies until August 25, 2020 [99]. The CDC Order forestalled residential evictions where a tenant met certain criteria between September 4 and December 31, 2020 [100].

Preliminary evidence suggests that these orders were effective: In the short period between when the CARES Act protections expired and when the CDC Order took effect, new eviction filings rose quickly to exceed historical levels in almost every site without a local moratorium [101]. Among the cities tracked by the Eviction Lab without moratoria, eviction filings rose as high as
$395 \%$ above historical weekly averages after the CARES Act expired [98]. Following the CDC Order, new filings dropped to as low as $83 \%$ below historical weekly averages [98]. The dramatic spike in filings once the CARES Act expired suggests the need to adopt and extend moratoria until housing is stabilized among highrisk populations.

Based on eviction tracking data, the Eviction Lab identified three drivers of the COVID-19 eviction crisis. First, a significant number of property owners use the eviction process as a rent collection tool, rather than a means of removing tenants for other reasons [102]. Second, many tenants are, and have historically been, evicted for small amounts of money-during the pandemic, typically less than the local median amount for 1 month's rent and as little as \$120 - showing that property owners seem to have a low threshold for profit loss before they consider displacing their tenants [103]. Third, evictions occur where tenants lacked legal protections or supports to contest evictions, especially as demand for legal assistance increased during the pandemic [104]. This helps explain why the effectiveness of the CDC moratorium was jurisdiction specific: local implementation, tenant education of rights, and enforcement had important effects on the moratorium's breadth in practice.

The Absence and Lifting of Eviction Moratoria Increases Spread of COVID-19 Infection and Mortality Rates

At least two studies demonstrate the potential association between the absence and lifting of eviction moratoria and increased COVID-19 infection and mortality rates [10]. In one model, researchers were primarily concerned with the epidemiological consequences of increased crowding as a result of eviction because evicted individuals tend to "double up," thereby increasing household size and boosting opportunities for viral spread [10]. With an eviction rate of $0.25 \%$ per month (significantly less than the $2 \%$ pre-pandemic national average), the model predicted a roughly $0.6 \%$ increase in total infections [10]. When applied to Philadelphia, a metro area with diverse housing stability and socioeconomic status representative of many major U.S cities, the model showed 7200 additional individuals would be infected by December 31,2020, if eviction rates return to pre-pandemic levels [10](p10). If levels increase to 5 times pre-pandemic rates due to a backlog of cases and 
widespread economic duress, as some analysts predict, excess infections could reach up to 41,000 by December $31,2020[10](\mathrm{p} 10)$.

In another study, researchers used varying expiration dates of state eviction moratoria to evaluate whether lifting moratoria was associated with increased COVID-19 spread and mortality [11]. After controlling for mask orders, stay at home orders, school closures, and testing rates, as well as characteristics of states and underlying time trends, this natural experiment showed that lifting moratoria was associated with 1.6 times higher COVID-19 mortality after 7 weeks and 5.4 times higher mortality after 16 weeks [11]. Similarly, lifting moratoria was associated with 1.6 times higher incidence of COVID-19 after 10 weeks and 2.1 times higher incidence after 16 weeks compared to maintaining eviction moratoria [11]. Lifting moratoriums translated to a total of 433,700 excess cases and 10,700 excess deaths between March 1 and September 3, 2020 [11]. Thus, eviction moratoria could be effective mechanisms for suppressing COVID-19 infection and mortality.

Supportive Measures May Aid in Prevention of Eviction and the Risk of COVID-19 Spread

Moratoria are critical emergency measures to control the spread of COVID-19 and protect renters from eviction and associated harms, including the immediate risk of infection. With supportive legal and financial measures, such as rental assistance [105], eviction diversion programs [106], and civil right to counsel [107], states and localities are better able to protect vulnerable residents from eviction. Rental assistance programs can eliminate accumulated rental debt, reduce rent burdens, and increase housing stability, especially among low-income renters who have experienced COVID-19-related job or income loss [108]. In one study, the Michigan Eviction Diversion Program resulted in a decrease in default judgments, orders of eviction, and dismissal rates by $11.5 \%, 12.6 \%$, and $5.5 \%$ respectively [109]. Similarly, the adoption of civil right to counsel in eviction cases consistently decreases eviction rates. In New York City, universal counsel for income-eligible tenants prevented the evictions of over 22,000 households [110]. Overall, in 2019 in New York City, 84\% of tenants who were represented by counsel avoided eviction and eviction rates dropped by $41 \%$, with eviction filings dropping by $34 \%$ and default judgments by $34 \%$ [111]. Similar outcomes were achieved in other cities with a civil right to counsel [112-114]. Tenants represented by attorneys are more likely to have knowledge of and exercise their rights under moratoria in order to maintain housing. Coupled with eviction moratoria, these supportive measures increase housing stability and, in turn, curb the spread of COVID-19.

Increasing health care access is also associated with reduced eviction rates. Policies such as Medicaid expansion can offer permanent pathways to reduce and prevent eviction and associated poor health outcomes. One study found that California counties that expanded Medicaid through the Affordable Care Act in 2011 and 2012 saw a significant reduction in evictions (24.5 fewer evictions per month per county from a previous average of 224.7) compared to counties in 14 other states which did not expand Medicaid [67]. The researchers hypothesize that by reducing or eliminating medical debt and the financial burden of medical care, more tenants are able to make timely rent payments thereby lowering eviction rates. Reduction in illness also increases the ability to seek and maintain employment [115].

The COVID-19 pandemic magnified the connection between housing and individual and public health, especially among low-income populations and people of color, and underscored the urgency of eviction prevention. However, the relationship between eviction and health equity will remain long after the pandemic's conclusion. Beyond pandemic stop-gap measures, it is critical to harness this period of political creativity to address the root causes of the housing and eviction crisis, in addition to immediate needs [93]. Only then will health equity and health justice be secured [93].

\section{Conclusion}

During the COVID 19 pandemic, widespread job and wage loss drastically increased housing precarity, especially among people of color, low-income populations, and members of society most vulnerable to COVID-19 infection, complication, and death. Eviction and housing displacement increases the spread of COVID-19 among the highest risk populations and triggers a cycle of poor health and housing instability. Protecting public health during a pandemic requires protecting those most likely to contract, spread, and die from infectious disease, including people in poverty and people of color, who are more likely to be evicted and more likely to suffer severe health harms during the pandemic. Studies 
suggest eviction moratoria may mitigate COVID-19 spread and death and can be bolstered with supportive measures. Housing displacement and eviction prevention can be a key component of a comprehensive strategy to control the pandemic by reducing COVID-19 infection, transmission, illness, hospitalizations, and death and to address health inequity.

Acknowledgments ${ }^{1}$ This article builds on research in an amici curiae $^{\dagger}$ brief filed on behalf of the American Academy of Pediatrics and its Georgia, North Carolina, Ohio, South Carolina, and Virginia chapters; the American Medical Association; and Children's Healthwatch, GLMA: Health Professionals Advancing LGBTQ Equality, National Hispanic Medical Association, National Medical Association, Public Health Law Watch and the George Consortium, the Southern Poverty Law Center, Professor Emily A. Benfer, Dr. Matthew Desmond, Dr. Gregg Gonsalves, Dr. Danya E. Keene, Dr. Kathryn M. Leifheit, Dr. Michael Z. Levy, Dr. Sabriya L. Linton, Dr. Craig E. Pollack, Dr. Julia Raifman, Dr. Gabriel L. Schwartz, and Dr. David Vlahov in Brown v. Azar in the U.S. District Court for the Northern District of Georgia (2020). The brief was authored by Emily A. Benfer (lead author), Wake Forest University School of Law; J.L. Pottenger, Jr. and Richard L. Tenenbaum, Jerome N. Frank Legal Services Organization, Yale Law School; and Wingo Smith, Southern Poverty Law Center, with the support of Yale Law School legal interns Salvatore Minopoli, Patrick Monaghan, Jacqui Oesterblad, Evan Walker-Wells, Logan Wren; and Wake Forest University School of Law legal intern Emilia Todd.

\section{References}

1. On the Brink of Homelessness: How the Affordable Housing Crisis and the Gentrification of America Is Leaving Families Vulnerable: Hearing Before the H. Comm. on Fin. Servs., 116th Cong. 3 (2020) (statement of Matthew Desmond, Maurice P. During Professor of Sociology, Princeton University). https://docs.house. gov/meetings/BA/BA00/20200114/110362/HHRG-116BA00-Wstate-DesmondM-20200114.pdf. Accessed October 1, 2020.

2. Greenberg D, Gershenson C, Desmond M. Discrimination in evictions: empirical evidence and legal challenges. Harv CR-CLL Rev. 2016; Accessed October 1, 2020.

3. America's Rental Housing 2020. Jt Cent Hous Stud Harvard Univ. 2020:4,26. https://www.jchs.harvard. edu/sites/default/files/Harvard_JCHS_Americas_Rental_ Housing_2020.pdf. Accessed October 1, 2020.

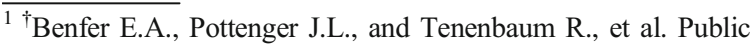
Health Amici Curiae Brief in Support of the Centers for Disease Control and Prevention Eviction Moratorium [Filed in the U.S. District Court for the Northern District of Georgia in Brown v. Azar, October 9, 2020, https://papers.ssrn.com/sol3/papers. cfm?abstract_id=3708504.
}

4. American Housing Survey, U.S. The United States Census Bureau website. https://www.census.gov/programssurveys/ahs/data/interactive/ahstablecreator.html. Accessed November 16, 2020.

5. The State of the Nation's Housing 2019. Jt Cent Hous Stud Harvard Univ. 2019:4. https://www.jchs.harvard. edu/sites/default/files/Harvard_JCHS_State_of_the Nations_Housing_2019.pdf. Accessed October 1, 2020.

6. The Gap: A shortage of affordable homes. Nat'l Low Income Housing Coalition. 2020:1. https://reports.nlihc. org/sites/default/files/gap/Gap-Report_2020.pdf. Accessed October 1, 2020.

7. Policy Responses to COVID-19 Policy Tracker. International Monetary Fund Website. Updated November 19, 2020. https://www.imf.org/en/Topics/imfand-covid19/Policy-Responses-to-COVID-19. Accessed November 22, 2020.

8. Wheelock DC. Comparing the COVID-19 recession with the Great Depression. Econ Synopses. 2020;39 https://doi. org/10.20955/es.2020.39.

9. Benfer EA, Robinson DB, Butler S, et al. The COVID-19 eviction crisis: an estimated 30-40 million people in America are at risk. The Aspen Institute. Published August 7, 2020. http://www.aspeninstitute.org/blogposts/the-covid-19-eviction-crisis-an-estimated-30-40million-people-in-america-are-at-risk. Accessed October 1, 2020.

10. Sheen J, Nande A, Walters EL, et al. The effect of eviction moratoriums on the transmission of SARS-CoV-2. medRxiv. 2020; https://doi.org/10.1101 /2020.10.27.20220897. Accessed November 11, 2020

11. Leifheit KM, Linton SL, Raifman J, Schwartz GL, Benfer EA, Zimmerman FJ, et al. Expiring Eviction Moratoria and COVID-19 Incidence and Mortality: Evidence from a Natural Experiment. 2020; https://doi.org/10.2139 /ssrn.3739576.

12. National Academies of Sciences, Engineering, and Medicine, Environmental Health Matters Initiative. In: Staudt A, Saunders J, Pavlin J, et al., editors. Airborne transmission of SARS-CoV-2: proceedings of a workshop-in brief. Washington (DC): National Academies Press (US); 2020. https://www.ncbi.nlm.nih. gov/books/NBK563528/. Accessed November 12, 2020.

13. Liu L, Li Y, Nielsen PV, Wei J, Jensen RL. Short-range airborne transmission of expiratory droplets between two people. Indoor Air. 2017;27(2):452-62. https://doi. org/10.1111/ina.12314.

14. Qian H, Miao T, Liu L, Zheng X, Luo D, Li Y. Indoor transmission of SARS-CoV-2. Indoor Air. 2020;12:1-7. https://doi.org/10.1111/ina.12766.

15. Leung NHL, Chu DKW, Shiu EYC, Chan KH, McDevitt JJ, Hau BJP, et al. Respiratory virus shedding in exhaled breath and efficacy of face masks. Nat Med. 2020;26:67680. https://doi.org/10.1038/s41591-020-0843-2.

16. Jarvis CI, Van Zandvoort K, Gimma A, et al. Quantifying the impact of physical distance measures on the transmission of COVID-19 in the UK. BMC Med. 2020;18:124. https://doi.org/10.1186/s12916-020-01597-8.

17. Desmond M. Eviction and the reproduction of urban poverty. Am J Sociol. 2012;118(1):88-133. https://doi. org/10.1086/666082. 
18. Desmond M, Gershenson C, Kiviat B. Forced relocation and residential instability among urban renters. Soc Serv Rev. 2015;89:227-62. https://doi.org/10.1086/681091.

19. Desmond M, Shollenberger T. Forced displacement from rental housing: prevalence and neighborhood consequences. Demography. 2015;52:1751-72. https://doi. org/10.1007/s13524-015-0419-9.

20. Collinson R, Reed D. The Effects of Evictions on LowIncome Households. Published December 2018. https://www.law.nyu.edu/sites/default/files/upload documents/evictions_collinson_reed.pdf. Accessed October 12, 2020.

21. Munywoki PK, Koech DC, Agoti CN, Bett A, Cane PA, Medley GF, et al. Frequent asymptomatic respiratory syncytial virus infections during an epidemic in a rural Kenyan household cohort. J Infect Dis. 2015;212(11):1711-8. https://doi.org/10.1093/infdis/jiv263.

22. Bakuli A, Klawonn F, Karch A, Mikolajczyk R. Effects of pathogen dependency in a multi-pathogen infectious disease system including population level heterogeneity-a simulation study. Theor Biol Med Model. 2017;14(1) https://doi.org/10.1186/s12976-017-0072-7.

23. Lofgren E, Fefferman NH, Naumov YN, Gorski J, Naumova EN. Influenza seasonality: underlying causes and modeling theories. J Virol. 2007;81(11):5429-36. https://doi.org/10.1128/JVI.01680-06.

24. Gleason BL, Foster S, Wilt GE, et al. Geospatial analysis of household spread of Ebola virus in a quarantined village Sierra Leone, 2014. Epidemiol Infect. 2017;145(14):29219. https://doi.org/10.1017/S0950268817001856.

25. Kermode M, Crofts N, Speed B, Miller P, Streeton J. Tuberculosis infection and homelessness in Melbourne, Australia, 1995-1996. Int J Tuberc Lung Dis. 1999;3(10): 901,905

26. Zolopa AR, Hahn JA, Gorter R, Miranda J, Wlodarczyk D, Peterson J, et al. HIV and tuberculosis infection in San Francisco's homeless adults: prevalence and risk factors in a representative sample. JAMA. 1994;272(6):455,458-61. https://doi.org/10.1001/jama.1994.03520060055032.

27. Baker M, McNicholas A, Garrett N, et al. Household crowding a major risk factor for epidemic meningococcal disease in Auckland children. Pediatr Infect Dis J. 2000;19(10):983-90. https://doi.org/10.1097/00006454200010000-00009.

28. Bi Q, Wu Y, Mei S, Ye C, Zou X, Zhang Z, et al. Epidemiology and transmission of COVID-19 in 391 cases and 1286 of their close contacts in Shenzhen, China: a retrospective cohort study. Lancet Infect Dis. 2020;20(8): 911-9. https://doi.org/10.1016/S1473-3099(20)30287-5.

29. Drucker E, Alcabes P, Sckell B, Alcabes P, Bosworth W. Childhood tuberculosis in the Bronx, New York. Lancet. 1994;343(8911):1482-5. https://doi.org/10.1016/S01406736(94)92588-7.

30. Yousey-Hindes KM, Hadler JL. Neighborhood socioeconomic status and influenza hospitalizations among children: New Haven County, Connecticut, 2003-2010. Am J Public Health. 2011;101(9):1785-9. https://doi. org/10.2105/AJPH.2011.300224.

31. Aligne CA. Overcrowding and mortality during the influenza pandemic of 1918. Am J Public Health. 2016;106(4): 642-4. https://doi.org/10.2105/AJPH.2015.303018.
32. Atlanta Georgia Code. III, appx. E, art. II, $\S \S 24,26$. Section 24(b), (e). Municode Library website. https://library.municode.com/ga/atlanta/codes/code_of ordinances? nodeId=PTIIICOORANDECO APXEATHOCO1987 ARTIIMIST S24MISPUSLORE

33. Rankin SK. Punishing homelessness. New Crim Law Rev. 2019;22(1):99, 126-135. https://doi.org/10.1525 /nclr.2019.22.1.99.

34. Centers for Disease Control \& Prevention. COVID-19 pandemic planning scenarios. CDC website. Updated September 10,2020 . https://www.cdc. gov/coronavirus/2019-ncov/hcp/planning-scenarios.html. Accessed November 16, 2020.

35. Pilkauskas NV, Garfinkel I, McLanahan SS. The prevalence and economic value of doubling up. Demography. 2014;51:1667-76. https://doi.org/10.1007/s13524-0140327-4.

36. Vacha EF, Marin MV. Informal shelter providers: low income households sheltering the homeless. J Soc Distress Homeless. 1993;2:117-33. https://doi. org/10.1007/BF01074225.

37. Harvard Medical School. COVID-19 Basics. Harvard Health Publishing. Published March 2020. Updated October 13, 2020. https://www.health.harvard. edu/diseases-and-conditions/covid-19-basics. Accessed November 16, 2020.

38. Tosevski DL, Milovancevic MP. Stressful life events and physical health. Curr Opin Psychiatry. 2006;19(2):184-9. https://doi.org/10.1097/01.yco.0000214346.44625.57.

39. Vásquez-Vera H, Palència L, Magna I, Mena C, Neira J, Borrell C. The threat of home eviction and its effects on health through the equity lens: a systematic review. Soc Sci Med. 2017;175:199-208. https://doi.org/10.1016/j. socscimed.2017.01.010.

40. Schmitt-Grohé S, Teoh K, Uribe M. Covid-19: Testing Inequality in New York City. Cent Econ Policy Res. 2020;8:27. https://cepr.org/content/covid-economicsvetted-and-real-time-papers-0. Accessed October 1, 2020.

41. Streeter RA, Snyder JE, Kepley H, Stahl AL, Li T, Washko MM. The geographic alignment of primary care health professional shortage areas with markers for social determinants of health. PLoS One. 2020;15(4):e0231443. https://doi.org/10.1371/journal.pone.0231443.

42. Kennedy MC, Kerr T, McNeil R, et al. Residential eviction and risk of detectable plasma HIV-1 RNA viral load among HIV-positive people who use drugs. AIDS Behav. 2017;21: 678,681-3. https://doi.org/10.1007/s10461-016-1315-z.

43. Niccolai LM, Blankenship KM, Keene DE. Eviction from renter-occupied households and rates of sexually transmitted infections: a county-level ecological analysis. Sex Transm Dis. 2019;46:63-8. https://doi.org/10.1097 /OLQ.0000000000000904.

44. Keene DE, Guo M, Murillo S. "That wasn't really a place to worry about diabetes": housing access and diabetes selfmanagement among low-income adults. Soc Sci Med. 2018; https://doi.org/10.1016/j.socscimed.2017.11.051.

45. Centers for Disease Control \& Prevention. Selected Circulatory Diseases Among Adults Aged 18 and Over, By Selected Characteristics: United States, 2018. CDC website. 2018. https://www.cdc.gov/nchs/nhis/shs/tables. $\mathrm{htm}$. Accessed November 16, 2020 
46. Centers for Disease Control \& Prevention. Diabetes Prevalence and Glycemic Control Among Adults Aged 20 and Over, By Sex, Age, and Race and Hispanic Origin: United States, Selected Years 1988-1994 Through 2013-2016. 2018. https://www.cdc. gov/nchs/data/hus/2018/014.pdf. Accessed October 1, 2020.

47. Centers for Disease Control \& Prevention. Selected Respiratory Diseases Among Adults Aged 18 and Over, By Selected Characteristics: United States. CDC website. 2018 . https://ftp.cdc.gov/pub/Health Statistics/NCHS/NHIS/SHS/2018_SHS_Table_A-2.pdf. Accessed November 17, 2020.

48. Riley ED, Hickey MD, Imbert E, Clemenzi-Allen AA, Gandhi M. COVID-19 and HIV spotlight the U.S. Imperative for permanent affordable housing. Clin Infect Dis. https://doi.org/10.1093/cid/ciaa1327.

49. Rodriguez A. Nearly half of all medical care in the US is in emergency departments. AJMC. Published October 24, 2017. https://www.ajmc.com/view/nearly-half-of-allmedical-care-in-the-us-is-in-emergency-departments

50. World Health Organization. Vulnerable Groups. WHO website. https://www.who.int/teams/environment-climatechange-and-health/emergencies. Accessed October 6, 2020\%.

51. Centers for Disease Control \& Prevention. People with Certain Medical Conditions. CDC website. https://www. cdc.gov/coronavirus/2019-ncov/need-extraprecautions/people-with-medical-conditions.html. Accessed September 11, 2020.

52. Centers for Disease Control \& Prevention. People at Increased Risk. CDC website. Updated September 11, 2020. https:/www.cdc.gov/coronavirus/2019-ncov/needextra-precautions/index.html?CDC_AA_refVal=https://. Accessed November 16, 2020.

53. Miller WD, Pollack CE, Williams DR. Healthy homes and communities: putting the pieces together. Am J Prev Med. $2011 ; 40: \mathrm{S} 48-57$. https://doi.org/10.1016/j. amepre.2010.09.024.

54. Benfer EA, Gold AE. There's no place like home: reshaping community interventions and policies to eliminate environmental hazards and improve population health for low-income and minority communities. Harv Law Policy Rev. 2017;11(2) https://papers.ssrn.com/sol3 /papers.cfm? abstract_id=3006099(Fixed spacing in URL)

55. Benfer EA, Robinson DB, Butler S, et al. The COVID-19 eviction crisis: an estimated 30-40 million people in America are at risk. The Aspen Institute. Published August 7, 2020. http://www.aspeninstitute.org/blogposts/the-covid-19-eviction-crisis-an-estimated-30-40million-people-in-america-are-at-risk. Accessed November 17, 2020.

56. Corporation for Supportive Housing. Housing is the Best Medicine: Supportive Housing and the Social Determinants of Health. Published July 2014. https://d155 kunxfl aozz.cloudfront.net/wp-content/uploads/2014/07 /SocialDeterminantsofHealth_2014.pdf. Accessed October $1,2020$.

57. Rojas Y. Evictions and short-term all-cause mortality: a 3year follow-up study of a middle-aged Swedish population.
Int J Public Health. 2017;62:343-51. https://doi. org/10.1007/s00038-016-0931-8.

58. Bolívar Muñoz J, Bernal Solano M, Mateo Rodríguez I, Daponte Codina A, Escudero Espinosa C, Sánchez Cantalejo C, et al. The health of adults undergoing an eviction process. Gac Sanit. 2016;30:4-10. https://doi. org/10.1016/j.gaceta.2015.10.002.

59. Pilarinos A, Kennedy MC, McNeil R, Dong H, Kerr T, DeBeck K. The association between residential eviction and syringe sharing among a prospective cohort of streetinvolved youth. Harm Reduct J. 2017;14:24. https://doi. org/10.1186/s12954-017-0150-5.

60. Kennedy MC, McNeil R, Milloy MJ, Dong H, Kerr T, Hayashi K. Residential eviction and exposure to violence among people who inject drugs in Vancouver, Canada. Int J Drug Policy. 2017;41:59-64. https://doi.org/10.1016/j. drugpo.2016.12.017.

61. Daoud N, Matheson FI, Pedersen C, Hamilton-Wright S, Minh A, Zhang J, et al. Pathways and trajectories linking housing instability and poor health among low-income women experiencing intimate partner violence (IPV): toward a conceptual framework. Women Health. 2016;56: 208-25. https://doi.org/10.1080/03630242.2015.1086465.

62. Collins AB, Boyd J, Damon W, Czechaczek S, Krüsi A, Cooper $\mathrm{H}$, et al. Surviving the housing crisis: social violence and the production of evictions among women who use drugs in Vancouver, Canada. Health Place. 2018;51: 174-81. https://doi.org/10.1016/j.healthplace.2018.04.001.

63. Wilson PR, Laughon K. House to house, shelter to shelter: experiences of black women seeking housing after leaving abusive relationships. J Forensic Nurs. 2015;11:77-83. https://doi.org/10.1097/JFN.0000000000000067.

64. Pollack CE, Leifheit KM, Linton SL. When storms collide: evictions, COVID-19, and health equity. Health Aff. 2020; https://www.healthaffairs.org/do/10.1377 /hblog20200730.190964/full/

65. Schwartz GL, Leifheit KM, Berkman B, Chen JT, Arcaya MC. Health selection into eviction: adverse birth outcomes and children's risk of eviction through age five [dissertation]. Harvard University. 2020:27-42. https://dash. harvard.edu/handle/1/37365869

66. Schwartz GL. Cycles of disadvantage: eviction \& children's health in the United States [dissertation]. Boston, Massachusetts: Harvard University; 2020. https://dash. harvard.edu/handle/1/37365869L)

67. Allen HL, Eliason E, Zewde N, Gross T. Can Medicaid expansion prevent housing evictions? Health Aff. 2019;38: 1451-7. https://doi.org/10.1377/hlthaff.2018.05071.

68. Desmond M. Evicted: poverty and profit in the American city. First ed. New York: Broadway Books; 2016.

69. Sandstrom H, Huerta S. The Negative Effects of Instability on Child Development: A Research Synthesis, vol. 3; 2013. p. 87-90.

70. Case Western Reserve University. Homelessness just 'one of the concerns' when someone is evicted. Newswise Published January 28, 2020. https://www.newswise. com/articles/homelessness-just-one-of-the-concerns-whensomeone-is-evicted. Accessed November 13, 2020.

71. Leifheit KM, Schwartz GL, Pollack CE, Black MM, Edin $\mathrm{KJ}$, Althoff $\mathrm{KN}$, et al. Eviction in early childhood and neighborhood poverty, food security, and obesity in later 
childhood and adolescence: evidence from a longitudinal birth cohort. SSM - Popul Heal. 2020;11:100575. https://doi.org/10.1016/j.ssmph.2020.100575.

72. Kottke T, Abariotes A, Spoonheim JB. Access to affordable housing promotes health and well-being and reduces hospital visits. Perm J. 2017; https://doi.org/10.7812 /TPP/17-079.

73. Gaetz S, Ward A, Kimura L. Youth homelessness and housing stability: what outcomes should we be looking for? Healthc Manag Forum. 2019;32:73-7. https://doi. org/10.1177/0840470418817333.

74. Dong M, Anda RF, Felitti VJ, Williamson DF, Dube SR, Brown DW, et al. Childhood residential mobility and multiple health risks during adolescence and adulthood: the hidden role of adverse childhood experiences. Arch Pediatr Adolesc Med. 2005 Dec;159(12):1104-10. https://doi.org/10.1001/archpedi.159.12.1104.

75. Leifheit KM, Schwartz GL, Pollack CE, Edin KJ, Black MM, Jennings JM, et al. Severe Housing Insecurity during Pregnancy: Association with Adverse Birth and Infant Outcomes. Int J Environ Res Public Health. 2020;17(22): 8659. https://apha.confex.com/apha/2019/meetingapp. cgi/Paper/444457.

76. Council on Community Pediatrics. Providing care for children and adolescents facing homelessness and housing insecurity. Pediatrics. 2013;131(6):1206-10. https://doi. org/10.1542/peds.2013-0.

77. Desmond M, Gershenson C. Housing and employment insecurity among the working poor. Soc Probl. 2016;63: 46-67. https://doi.org/10.1093/socpro/spv025.

78. Desmond M, Bell M. Housing, poverty, and the law. Annu Rev Law Soc Sci. 2015;11:15-35. https://doi.org/10.1146 /annurev-lawsocsci-120814-121623.

79. Allen HL, Eliason E, Zewde N, Gross T. Can Medicaid expansion prevent housing evictions? Health Aff. 2019;38(9):1451-15. https://doi.org/10.1377 hlthaff.2018.05071.

80. Franzese PA. A place to call home: tenant blacklisting and the denial of opportunity. Fordham Urb LJ. 2018;45(3) https://ir.lawnet.fordham.edu/ulj/vol45/iss3/2

81. Teresa BF. The geography of eviction in Richmond: beyond poverty. RVA Eviction Lab. 2017; https://cura.vcu. edu/media/cura/pdfs/curadocuments/GeographiesofEviction. pdf. Accessed November 16, 2020

82. Hartman C, Robinson D. Evictions: the hidden housing problem. Hous Policy Debate. 2003;14:461-501. https://doi.org/10.1080/10511482.2003.9521483.

83. Dovey R. What 80 million eviction records can tell city leaders. Next City. Published April 9, 2018. https://nextcity.org/daily/entry/what-80-million-evictionrecords-can-tell-city-leaders. Accessed November 16, 2020.

84. Beiers S, Park S, Morris L. Clearing the record: how eviction sealing laws can advance housing access for women of color. ACLU. Published January 10, 2020. https://www.aclu.org/news/racial-justice/clearing-therecord-how-eviction-sealing-laws-can-advance-housingaccess-for-women-of-color/. Accessed November 16, 2020.

85. Jones J. The racial wealth gap: how African-Americans have been shortchanged out of the materials to build wealth: Economic Policy Institute: Working Economics Blog; 2017. http://www.epi.org/blog/the-racial-wealthgap-how-african-americans-have-been-shortchanged-outof-the-materials-to-build-wealth

86. Rothstein R. The color of law: a forgotten history of how our government segregated America. New York; London: Liveright Publishing Corporation, a division of W.W. Norton \& Company; 2017.

87. Lopez MH, Rainie L, Budiman A. Financial and health impacts of COVID-19 vary widely by race and ethnicity. Pew Research Center website May 5, 2020. https://pewrsr. ch/2L15rwr. Accessed November 16, 2020.

88. Week 14 Household Pulse Survey: September 2 September 14, Table 2b. United States Census Bureau website. Published September 23, 2020. https://www. census.gov/data/tables/2020/demo/hhp/hhp14.html. Accessed November 22, 2020.

89. COVID-19 Hospitalization and Death by Race/Ethnicity. Centers for Disease Control \& Prevention website. August 18, 2020. http://www.cdc.gov/coronavirus/2019ncov/covid-data/investigations-discovery/hospitalizationdeath-by-race-ethnicity.html.

90. The COVID Racial Data Tracker. The COVID Tracking Project at The Atlantic website. Accessed October 5, 2020. http://covidtracking.com/race.

91. APM Research Lab Staff. The Color of Coronavirus: COVID-19 Deaths by Race and Ethnicity in the U.S. APM Research Lab. 2020. https://www.apmresearchlab. org/covid/deaths-by-race.

92. Ford T, Reber S, Reeves RV. Race gaps in COVID-19 deaths are even bigger than they appear. Brookings June 16, 2020. https://brook.gs/3lrRBU2

93. Benfer EA, Mohapatra S, Wiley FL, Yearby R. Health justice strategies to combat the pandemic: eliminating discrimination, poverty, and health inequity during and after COVID-19. Yale J Health Policy Law Ethics. 2020; https://doi.org/10.2139/ssrn.3636975.

94. Geronimus AT, Hicken M, Keene D, Bound J. "Weathering" and age patterns of allostatic load scores among blacks and whites in the United States. Am J Public Health. 2006; https://doi.org/10.2105 /AJPH.2004.060749.

95. Benfer E. Health justice: a framework (and call to action) for the elimination of health inequity and social justice. $A m U L$ Rev. 2015;65(2):275. https://ssrn.com/abstract=2672396

96. Benfer EA, Adam K, Koehler R, Mark A, et al. COVID-19 eviction moratoria \& housing policy: federal, state, commonwealth, and territory. Published 2020. Accessed November 19, 2020.

97. Benfer EA. COVID-19 housing policy scorecard. Eviction Lab. 2020; https://evictionlab.org/covidpolicy-scorecard/. Accessed November 22, 2020.

98. Eviction Lab. The eviction tracking system. Eviction Lab website. Updated September 26, 2020. http://evictionlab. org/eviction-tracking. Accessed November 16, 2020.

99. Coronavirus Aid, Relief, and Economic Security (CARES) Act, Pub. L. No. 116-136, § 4024, 134 Stat. 281, 491 (2020).

100. National Housing Law Project. CDC eviction moratorium - initial analysis. NHLP. Published September 4, 2020. 
https://www.nhlp.org/wp-content/uploads/CDC-EvictionAnalysis.pdf

101. Hepburn P, Louis R. Preliminary analysis: shifts in eviction filings from the CARES Act to the CDC Order. Eviction Lab. 2020; https://evictionlab.org/shifts-in-eviction-filingsfrom-cares-act-to-cdc-order/.

102. Leung L, Hepburn P, Desmond M. Serial eviction filing: civil courts, property management, and the threat of displacement. Soc Forces. 2020; https://doi.org/10.1093 /sf/soaa089.

103. Louis R, Durana A, Hepburn P. Preliminary analysis: eviction claim amounts during COVID-19 pandemic. Eviction Lab Published August 27, 2020. https:/evictionlab. org/covid-eviction-claims

104. Desmond M. Unaffordable America: poverty, housing, and eviction. Fast Focus Inst Res Poverty. March 2015;22-2015:16. https://www.irp.wisc.edu/publications/fastfocus/pdfs/FF222015.pdf

105. Keene DE, Niccolai L, Rosenberg A, Schlesinger P, Blankenship KM. Rental assistance and adult self-rated health. J Health Care Poor Underserved. 2020;31(1): 325-39. https://doi.org/10.1353/hpu.2020.0025.

106. Eviction diversion programs. National Center for State Courts website. https: //www.ncsc.org/information-andresources/trending-topics/trending-topics-landingpg/eviction-diversion-programs. Accessed October 25, 2020.

107. Stout Risius Ross. The Financial Cost and Benefits of Establishing a Right to Counsel in Eviction Proceedings Under Intro 214-A. Presented March 16, 2016. https://www2.nycbar.org/pdf/report/uploads/SRR Report_Financial_Cost_and_Benefits_of_Establishing_a Right_to_Counsel_in_Eviction_Proceedings.pdf

108. National Low Income Housing Coalition. Emergency Rental Assistance Programs in Response to COVID-19. Published October 27, 2020. https://nlihc. org/sites/default/files/Emergency-Rental-AssistancePrograms-3.pdf. Accessed October 28, 2020.
109. Gamber N, Galvin J, Sanders A. An analysis of the eviction program at the 54-a district court. Published 2017. https://www.lansingmi.gov/DocumentCenter/View/5528 /2017-Eviction-Diversion-Pilot-Program-Final-Report. Accessed October 28, 2020.

110. America's Rental Housing. Joint Ctr. For Housing Stud of Harv. U. 2020. https://www.jchs.harvard. edu/sites/default/files/Harvard_JCHS_Americas_Rental_ Housing 2020.pdf. Accessed October 28, 2020.

111. New York City Office of Civil Justice 2019 Annual Report. New York City Human Resources Administration, Department of Social Services 2019. https://www1.nyc. gov/assets/hra/downloads/pdf/services/civiljustice/OCJ Annual_Report_2019.pdf. Accessed October 28, 2020.

112. STOUT. Economic Return on Investment of Providing Counsel in Philadelphia Eviction Cases for Low-Income Tenants. Published November 13, 2018. https://www.philadelphiabar. org/WebObjects/PBA.woa/Contents/WebServerResources/ CMSResources/PhiladelphiaEvictionsReport.pdf. Accessed October 28, 2020.

113. Grundman L, Kruger M. Legal representation in evictions comparative study. Published 2018. https://www. minnpost.com/wp-content/uploads/2018/11/2018Eviction-Representation-Results-Study-with-logos.pdf. Accessed October 28, 2020.

114. Boston Bar Association Task Force on the Civil Right to Counsel. The Importance of Representation in Eviction Cases and Homelessness Prevention. Published March 2012. https://bostonbar.org/docs/default-documentlibrary/bba-crtc-final-3-1-12.pdf. Accessed October 28, 2020.

115. Keene DE, Lynch JF, Baker AC. Fragile health and fragile wealth: mortgage strain among African American homeowners. Soc Sci Med. 2014;118:119-26.

Publisher's Note Springer Nature remains neutral with regard to jurisdictional claims in published maps and institutional affiliations. 